\title{
The command to love the neighbour in Paul and the Synoptics
}

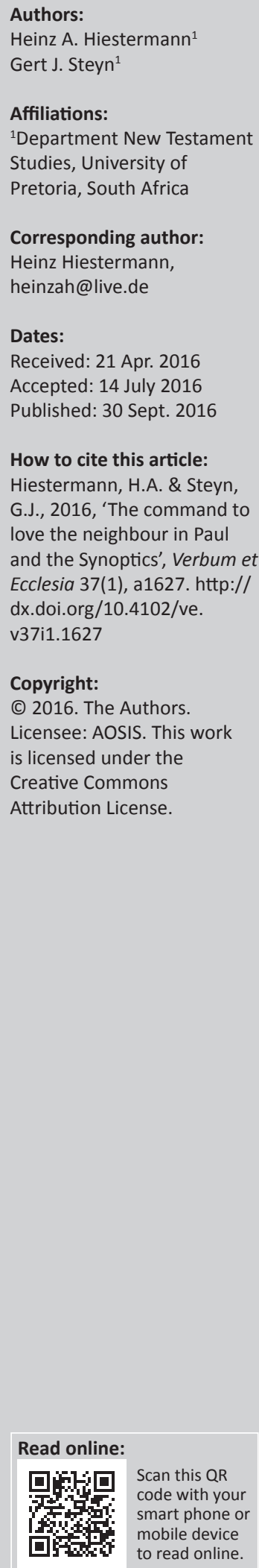

When sayings of Jesus are compared between the Pauline letters and the Synoptic Gospels in an attempt to locate parallels, Galatians 5:14 and Romans 13:8-10 have frequently been put forward as possible parallels to the Synoptic renditions of the great commandment of Mark 12:28-34 (Mt 22:34-40; Lk 10:25-28). These Pauline and Synoptic texts all contain the command to love the neighbour, but the Synoptic texts have added the command to love God to the command to love the neighbour. Paul never quoted the great commandment. Consequently, a relationship between the verses is normally rejected. However, not all possibilities have been explored. In the search for parallels between Pauline and Synoptic Jesus traditions it has been overlooked that Paul and Matthew render the command to love the neighbour more than once. Matthew delivers the command to love the neighbour three times. Only once he has connected it to the command to love God. Matthew renders the single command to love the neighbour twice, resembling the Pauline use of the command. Using the criteria for validating parallels between Pauline and Synoptic Jesus traditions, including verbal agreement and the unique use of the command to love the neighbour by Paul and Matthew, it is argued that a connection between Romans 13:9 and Matthew 19:18-19 is likely.

Intradisciplinary and/or interdisciplinary implications: The research explores the use of Leviticus 19:18b by the New Testament authors. It is argued that the command to love the neighbour was given high prominence in the early church, as it was used by the Synoptic authors and by Paul to summarise Jesus' ethical teachings.

\section{Introduction}

\section{Problem statement}

In the search for parallels between Jesus traditions in Paul's genuine letters and the Synoptic Gospels, Galatians 5:14 and Romans 13:9 have occasionally been considered as parallels to Mark 12:28-34 (Mt 22:34-40; Lk 10:25-28). These Pauline and Synoptic texts all contain the command to love the neighbour. However, a proposed relationship between the texts is often dismissed, as the Pauline texts differ too much from their Synoptic counterparts (cf. Allison 1982:5). The Synoptic accounts contain the double commandment to love God and the neighbour, while Galatians 5:14 and Romans 13:9 only contain the single command to love the neighbour. The Pauline parallels omit the command to love God. Paul never cites the great commandment as such and consequently a relationship between the Pauline and Synoptic texts is rejected, even though all the verses contain the command to love the neighbour. Walter (1985:512-513) even argues that Paul is consciously contradicting the Jesus tradition since he omits the command to love God, and Neirynck (1986:293) comments that Paul's failure to reproduce the great commandment 'presents "a grave difficulty to those, who [...] wish to see Paul reverently dependent upon Jesus's words"'.

A possible parallel between Galatians 5:14 and Romans 13:9 and the Synoptic rendition of the great commandment in Mark 12:28-34 (Mt 22:34-40; Lk 10:25-28) is rightly disregarded because of the evident differences between the texts. Yet, it has been overlooked in the search for parallels that Paul and Matthew both deliver the command to love the neighbour more than once (Rm 13:9; G1 5:14; Mt 5:43; 19:19, 22:39). Mark and Luke include the command to love the neighbour only once as part of the great commandment. Matthew renders the command to love the neighbour as part of the great commandment in Matthew 22:39 and he quotes the single command to love the neighbour from Leviticus 19:18b in Matthew 5:43; 19:19. This makes Matthew 5:43; 19:19 comparable with Galatians 5:14 and Romans 13:9, because all of these verses contain only a single command to love the neighbour. When possible parallels between the Pauline and Synoptic Jesus traditions are compared, the two Matthean verses containing the single command to love the neighbour (Mt 5:43; 19:19) have not been sufficiently considered as parallels to the Pauline rendition of the command to love the neighbour. 


\section{Methodology}

In the search for parallel sayings of Jesus in the Pauline letters and the Synoptic Gospels, numerous possible parallels are rejected for primarily two reasons. The first reason is that there is no substantial verbal agreement connecting possible parallel verses. Occasionally, statements in the Pauline letters and the Synoptics have the same meaning or express a similar idea, and consequently a relationship between the verses is assumed. However, the lack of agreement in wording between Pauline and Synoptic Jesus traditions makes a dependency of the parallels extremely difficult to prove. One cannot verify that Paul is reproducing a Jesus tradition when the wording of the Pauline parallels does not clearly indicate that he is quoting. If Paul is using words that he otherwise does not use or uses seldom, and these words are commonly found in the Synoptics, it can be argued that Paul is incorporating Jesus traditions into his letters. Since the search for parallels between the Pauline and Synoptic Jesus traditions undoubtedly 'involves a fair degree of subjectivity' (Kim 2002:275), verbal agreement has to remain a criterion to gain a level of objectivity.

The second frequent reason for discarding possible parallel sayings between Pauline and Synoptic Jesus traditions is that many of Jesus' sayings resemble widespread Jewish or Hellenistic teachings of the 1st century (cf. Furnish 1993:51). In such cases, it is impossible to be sure that Paul and the Synoptic authors were drawing on Jesus traditions and not on popular teachings of the time. Wilson (1984:15) argues: 'Some of the best parallels are not so much evidence for a connection between Jesus and Paul as for a connection of each of them with his Jewish environment'. One must be able to classify the statements in proposed parallels as specific Christian teachings, if one is to assume a dependency between similar Pauline and Synoptic texts. Kim (2002:275) calls this 'the principle of dissimilarity'.

When comparing the Pauline texts containing the single command to love the neighbour (G1 5:14; Rm 13:9) to possible Synoptic parallels (Mt 5:43; 19:19), the closest relationship exists between Romans 13:9 and Matthew 19:19. The command to love the neighbour from Leviticus $19: 18 \mathrm{~b}$ is

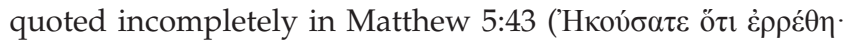

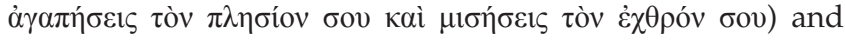
Paul does not reproduce a similar saying to this Matthean verse from the Sermon on the Mount. A substantial parallel between Matthew 5:43 and the Pauline verses cannot be proven.

Below the commands to love the neighbour from Romans 13:9 and Matthew 19:19 are examined in their respective contexts. Thereafter, the criterion of verbal agreement and the 'principle of dissimilarity' are applied in the comparison of Romans 13:9 with Matthew 19:19 in an attempt to determine if a relationship between the Pauline and Matthean commands to love the neighbour exists.

\section{The context of the Pauline command to love the neighbour}

Owing to the dating of Paul's letters prior to the Synoptics, Paul's rendition of the love command is the first written contribution about loving the neighbour in the emerging Christendom (Wischmeyer 1986:161). Paul quotes the command to love the neighbour from the LXX Leviticus 19:18b in Romans 13:9 and Galatians 5:14. He also commands love towards the neighbour in Romans 13:8, 10, but there he does not directly quote Leviticus 19:18b. The three verses commanding love to the neighbour in Romans 13:8-10 are part of the greater passage Romans 12:1-15:13. The chapters contain many ethical teachings and in the exhortations of these chapters, Paul takes up various traditional materials (Lohse 2003:332), including a number of sayings similar to those attributed to Jesus according to the Synoptics Gospels in Romans 12:14-21 (cf. Schnelle 2014:96). The topic of love is prevalent in Romans 12. Paul starts Romans 13, the chapter in which he quotes the command to love the neighbour, by discussing obedience to the state in verse $1-7$. In verse 8-10, he returns to the topic of love (Haacker 2006:303). The general paraenesis of chapters $12-13$ is summarised in Romans 13:8-10 with the command to love the neighbour (cf. Wilckens 2010:71).

When Paul quotes the command to love the neighbour in Romans 13:8-10 as part of the culmination of the ethical teachings of chapters 12-13, he lists a selection of Decalogue commandments in Romans 13:9. Similar lists of Decalogue commandments are found in all three of the Synoptics, but only in Matthew 19:18-19 the Pauline combination of the command to love the neighbour and a selection of Decalogue commandments is reproduced. In Galatians 5:14, the command to love the neighbour is quoted without the Decalogue commandments, excluding it as a possible parallel to Matthew 19:18-19. The probability that Paul was influenced by Jesus' words about loving the neighbour will be discussed next, by examining the way it was used in the Synoptic Gospels.

\section{The context of the Synoptic command to love the neighbour}

The possible parallel to Romans 13:9 in Matthew 19:18-19 is located in the Synoptic account of the rich young man. The account is rendered in all three of the Synoptic Gospels. The narrative tells 'the story of a young man whose great riches kept him from the full and unreserved commitment required of one who would become a disciple' (Hagner 1995:555). The young man came to Jesus and asked him: 'Good Teacher,

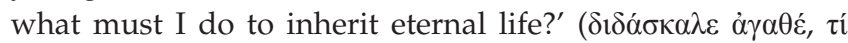

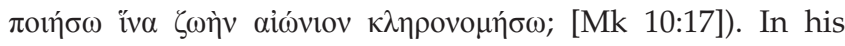
response, Jesus asked the young man why he called him

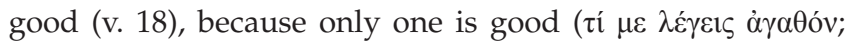

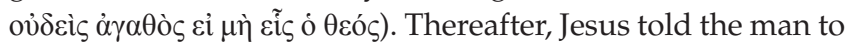
keep the commandments. While doing so, Jesus listed some of the Decalogue commandments but not the complete 
Decalogue. The list of Decalogue commandments resembles Romans 13:9, where Paul presents a similar collection of Decalogue commandments. Only in the Matthean version of the rich young man (Mt 19:16-22), the command to love the neighbour is connected to a list of Decalogue commandments. The parallel accounts in Mark 10:17-31 and Luke 18:18-30 omit the command to love the neighbour.

While the Synoptic renditions of the great commandment in Mark 12:28-34 (Mt 22:34-40; Lk 10:25-28) have been widely rejected as parallels to the Pauline command to love the neighbour, the Synoptic account of the rich young man is related to the Synoptic rendition of the great commandment. This is exemplified by Luke's Gospel in particular. In Luke's introduction into the account of the great commandment (Lk 10:25), a lawyer asks Jesus: 'Teacher, what shall I do to

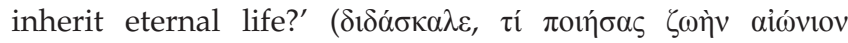

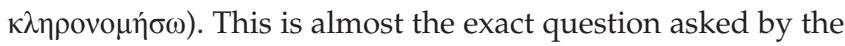

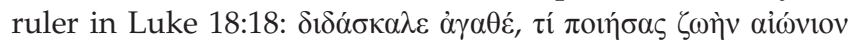
$\kappa \lambda \eta \rho о v о \mu \eta ́ \sigma \omega$. In the second instance, Jesus is called a 'good' teacher; otherwise, the question introducing the passages is the same. Luke thus delivers two different accounts starting with the same introductory question. It is the same question as the one asked in Mark in the narrative of the rich young man (Mk 10:17 = Lk 18:18). Matthew 19:16 is slightly different, because the rich man asks: 'Teacher, what good deed must

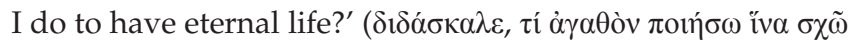

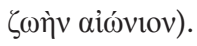

In Mark and Matthew's accounts of the great commandment, Jesus' counterpart did not ask what he should do to enter eternal life, as in Luke's Gospel. According to Mark 12:28, he

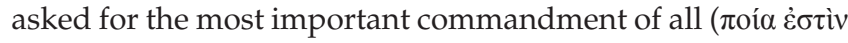

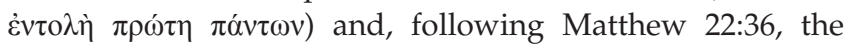
lawyer wanted to know: 'Teacher, which is the great

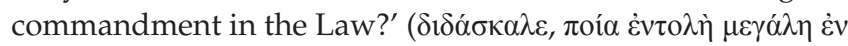
$\tau \tilde{\varphi}$ vó $\mu \omega)$. In other words, in the account of the great commandment as well as in the narrative of the rich young man, Jesus is asked to somehow summarise what is important (cf. Berger 1972:396), and in both Synoptic accounts a set of commandments is contained in the answer. The account of the great commandment gives the double commandment of loving God and the neighbour as answer, while the narrative of the rich young man lists some of the Decalogue commandments when declaring what is important when following Jesus. The attempt to summarise the commandments makes the two Synoptic accounts comparable. This resembles the use of the Decalogue commandments in Romans 13:9, where Paul closed his ethical paraenesis, using a list of Decalogue commandments. Therefore, the use of the list of Decalogue commandments in Paul and the Synoptics is comparable. The agreements between the Synoptic accounts of the great commandment and the rich young man possibly explain why both Synoptic passages are thought to be sharing similarities with Paul's rendition of the command to love the neighbour.

\section{The verbal agreement between the Pauline and Synoptic commands to love the neighbour}

Figure 1 contains the list of Decalogue commandments connecting Romans 13:9 and the Synoptic accounts of the rich young man.

The comparison shows that the Decalogue is quoted incompletely in all four of the New Testament renditions. Although the Decalogue 'formed the heartbeat of the Jewish religion' (Steyn 1996:453), the incomplete quotation of the Decalogue should not come as a surprise, since in early Christianity the Decalogue was seldom quoted as a whole. It was much rather common that only a few commandments from the second table were listed together (cf. Wilckens 2010:69-70). Therefore, one should not expect Paul and the Synoptic authors to have rendered the whole Decalogue.

None of the four New Testament versions is identical to any other version. The order cited by Paul is encountered in LXX Deuteronomy 5:17-19 (B) (Wilckens 2010:69). Luke and James follow this order too, as do Philo and Papyrus Nash. It was the most frequently cited order at the time (Schmid 2013:590). Matthew and Mark follow the order of the Masoretic text, but in the LXX translation (cf. Wiefel 1998:338). The relationship between the different lists of Decalogue commandments is complex and has been discussed by Steyn $(1996,2013)$ and Schmid (2013) and will not be repeated here. Steyn (1996) and Schmid (2013) have also discussed the textual criticism of the different New Testament versions of the Decalogue commandments.

Important for the question of whether a relationship between Paul's and Matthew's renditions of the command to love the neighbour can be established is that only Paul and Matthew combine a selection of Decalogue commandments with the command to love the neighbour. This combination is unique

\begin{tabular}{|c|c|c|c|c|}
\hline Romans 13:9 & Matthew 19:18-19 & Mark 10:19 & Luke 18:20 & Exodus 20:12-17 LXX \\
\hline 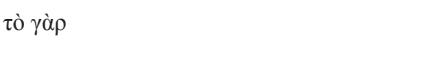 & tò & $\mu \grave{\eta} \varphi o v \varepsilon v ́ \sigma \eta \varsigma$ & 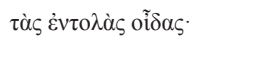 & 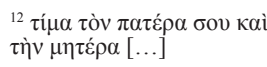 \\
\hline ov̉ $\mu о \imath \chi \varepsilon v ́ \sigma \varepsilon เ \varsigma$, & 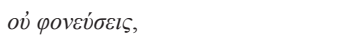 & 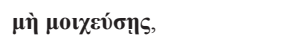 & 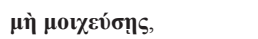 & 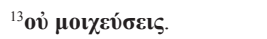 \\
\hline 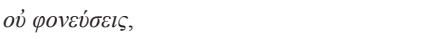 & ov̉ $\mu 0 เ \chi \varepsilon v ́ \sigma \varepsilon เ \varsigma$, & 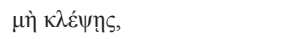 & $\mu \grave{\eta} \varphi o v \varepsilon v ́ \sigma \eta \varsigma$ & 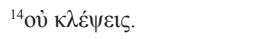 \\
\hline 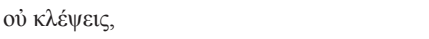 & 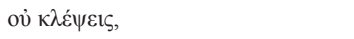 & 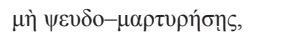 & 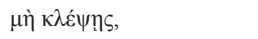 & 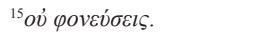 \\
\hline 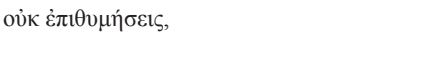 & 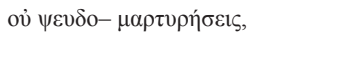 & 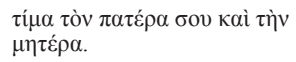 & 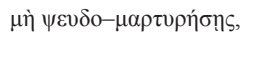 & ${ }^{16}$ ov̉ $\psi \varepsilon v \delta o-\mu \alpha \rho \tau v \rho \eta ́ \sigma \varepsilon เ \varsigma$ \\
\hline 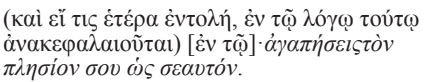 & 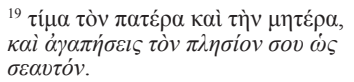 & 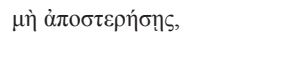 & 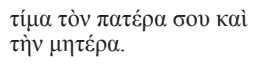 & 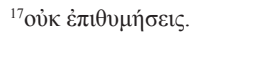 \\
\hline
\end{tabular}

FIGURE 1: List of Decalogue commandments connecting Romans 13:9 and the Synoptic accounts of the rich young man. 
in the New Testament. Mark and Luke omit the command to love the neighbour in their accounts of the rich young man and in Galatians 5:14 and in Matthew 5:43 the command to love the neighbour is quoted without the Decalogue commandments.

Another striking feature in the comparison is that Mark and Luke on the one hand, and Paul and Matthew on the other, formulate their commandments differently. Paul and Matthew use ov and the second person singular, future indicative active, compared with Mark's and Luke's formulation with $\mu$ í and the second person singular, aorist conjunctive active. James 2:11 is comparable with the Markan and Lukan formulation. James only quotes two Decalogue

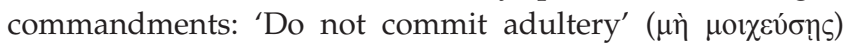

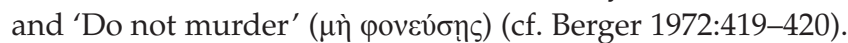
The linguistic differences between the various renditions of Decalogue commandments are significant because the formulation of Mark, Luke and James with $\mu$ í and the conjunctive is unusual (cf. Berger 1972:419). Mark's formulation in particular is strange, as he 'is usually in close adherence to the LXX when using formal quotations from his Jewish scrolls' (Steyn 1996:456). Paul and Matthew follow the LXX when formulating the commandments with ov and in the future indicative tense.

Despite the linguistic and stylistic similarities between the Pauline and Matthean versions, there are some notable differences between the two passages. In the New Testament,

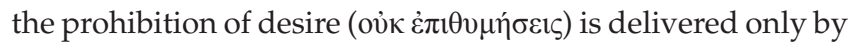
Paul in Romans, and the Pauline passage lacks the commandments 'Honor your father and mother' ( $\tau \dot{i} \mu \alpha$ tòv

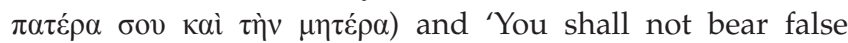

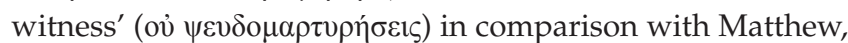
Mark and Luke. Matthew (and Mark), in comparison to Paul (and Luke), also invert the order of the first two commandments they list.

Paul and Matthew do share significant verbal agreements in Romans 13:9 and Matthew 19:18-19 because of their unique combination of the command to love the neighbour and a selection of Decalogue commandments. However, the differences between the texts means that a relationship between Romans 13:9 and Matthew 19:18-19 can only be assumed if the 'principle of dissimilarity' applies, that is, if the combination of the command to love the neighbour and the list of Decalogue commandments is unique, and no Jewish or Hellenistic sources exist from which Paul and Matthew could have copied from.

\section{The dissimilarity of the Pauline and Synoptic commands to love the neighbour to ancient parallels}

The command to love the neighbour is known in ancient parallels, both as combination with the command to love God, and on its own. What is striking, though, is that in ancient literature neither the great commandment nor the single command to love the neighbour is expressed by an actual citation from the Old Testament (cf. France 2007:477, 481; Johnson 2005:203). It is commanded to love God and the neighbour, but Deuteronomy 6:4-5 and Leviticus 19:18 are not quoted when formulating the commands (cf. Wischmeyer 1986:163-164). Only after Paul had quoted Leviticus 19:18 is it quoted in Jewish literature, for example, in Sipra Lv. 200 of Rabbi Aqiba (cf. Wischmeyer 1986:164). The absence of direct references to Leviticus 19:18b is highlighted by the fact that Jewish-Hellenistic parallels before Paul usually do not

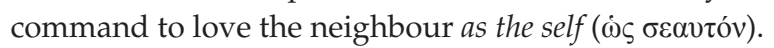

In addition to the failure of extra-biblical literature before Paul to quote Leviticus 19:18b, further observations cast doubt over a dependency of the New Testament command to love the neighbour on older extra-biblical material. In the New Testament, the command to love the neighbour is rendered when the law is summarised ( $\mathrm{Rm}$ 13:9; Mt 19:19), indicating the importance of the command, but in Jewish literature, the command to love the neighbour does not have the same prominence (cf. Dunn 1993:29). Dunn (1993:291) argues: 'The stimulus to focus thus on Lev. xix.18 must therefore be peculiarly Christian and is best explained as deriving from Jesus himself, as the Synoptic traditions indicate'. Strack and Billerbeck (1979:353-368) also differentiate the Christian command to love the neighbour from its Jewish parallels. They argue that when Paul and the Synoptic Gospels command love for the neighbour, all people are included in the commandment. In contrast, the Jewish literature only commands love to the fellow Jew, or in some cases, the proselyte, when they command to love the neighbour.

Furthermore, Furnish underlines a difference between the Pauline and Synoptic meaning of the command to love the neighbour in comparison to Hellenistic teachings. He remarks that 'the Hellenistic popular philosophers of Paul's day would have found it hard to agree that freedom consists in servant concern for others' (Furnish 1973:97-98). They would not have agreed to the Pauline statement in Galatians 5:14 that 'to be bound in Christ means to be bound to one another in a love that cares and that serves' (Furnish 1973:97-98).

The above arguments all point to differences in the use of the command to love the neighbour in the New Testament when compared with the Jewish or Hellenistic application of the command. Assuming a relationship between the Pauline and Synoptic use of the command to love the neighbour therefore is plausible, but some doubt remains. Even though Leviticus $19: 18 b$ is not quoted in the extra-biblical parallels, the frequent use of the commandment in these texts could have influenced the New Testament authors' use of the command to love the neighbour.

More certainty is found with regard to the combination of Decalogue commandments with the command to love the neighbour. The list of a selection of Decalogue commandments 
is not distinctive in itself. It is found in extra-biblical sources, for example, in Philo, Decalogue, 36, 51 (cf. Schmid 2013:590) and in Lib Ant XI 10-13 (cf. Wilckens 2010:69). The occurrence of other lists of Decalogue commandments means that the Pauline and Synoptic lists of commandments are not necessarily dependent on one another.

However, the combination of Decalogue commandments with the command to love the neighbour is distinctive. This combination is found only in Romans 13:9 and Matthew 19:18-19. There are no extra-biblical examples of the command to love the neighbour as the self's being joined to other Decalogue commandments. It did occur that the Decalogue was connected to the golden rule or the Shema Yisrael (cf. Berger 1972:265-267), but the combination of Decalogue commandments with the command to love the neighbour is otherwise unknown (cf. Wischmeyer 1986:168).

Berger (1972:390) lists Jubilees 7:20 as an example of Decalogue commandments combined with the command to love the neighbour. The verse from the Book of Jubilees cannot, however, be regarded as a real parallel to Romans 13:9. In Jubilees 7:20, only one Decalogue commandment ('honour father and mother') is listed together with other commands (which do not stem from the Decalogue), as well as with the command to love the neighbour. It can also be added that, in the verse from the Book of Jubilees, Leviticus 19:18 is not quoted verbatim as it is not commanded to love the neighbour as the self. For these reasons, it is not likely that there is any connection between Romans 13:9 and Jubilees 7:20. Romans 13:9 not only lacks Jewish parallels but also lack Greek or Latin templates linking Decalogue commandments to the command to love the neighbour. The New Wettstein lists no suitable parallels to Romans 13:9 and Matthew 19:18-19 (cf. Schnelle 2009:506-511).

In other words, there are no Jewish or Hellenistic texts explicitly combining a selection of Decalogue commandments with the command to love the neighbour. The unique combination of these commands and its difference from the Jewish theology of its time indicates a dependency of the renditions of Paul and Matthew. There are no known templates Paul and Matthew could have used or quoted from when formulating Romans 13:9 and Matthew 19:18-19.

The differences between the Pauline and Matthean accounts make it difficult to establish a more precise relationship between the texts. However, it can be assumed that they share a common tradition, because Romans 13:9 and Matthew 19:18-19 combine a list of Decalogue commandments with Leviticus 19:18b, and there are no comparable extra-biblical texts.

\section{Conclusion}

The command to love the neighbour is found in the Synoptic Gospels as part of the great commandment and, in Matthew, on its own. Paul never cites the great commandment, making a connection between the Synoptic account of the great commandment and Pauline literature unlikely. Matthew's rendering of the single command to love the neighbour in connection with a selection of Decalogue commandments in Matthew 19:18-19 strongly resembles Romans 13:9, where the same combination is found:

The connection between the commandments in the second table of the Decalogue and Leviticus 19:18 must have taken place during the early beginnings of Christianity in order to combine the commandments of the Decalogue with the interpretation of the Jesus tradition. (Steyn 1996:455)

This observation makes it likely that a common tradition between the Pauline and Matthean texts can be assumed, even though the number and order of Decalogue commandments listed by Paul differ slightly from those of Matthew.

Matthew delivers the combination of the command to love the neighbour with Decalogue commandments in his rendition of the narrative of the rich young man. Only Matthew uses the command to love the neighbour in this context. The relationship between the three Synoptic versions of the narrative of the rich young man has puzzled researchers for many years, as there are many divergences in the respective accounts. The differences between Mark (who is assumed to be the source of Matthew and Luke's versions; cf. Luz 1989:510) and Matthew, for example, are so vast, that one has to assume that the Markan passage was 'extensively reworked' by Matthew, even 'more so than is usually the case and with a number of special interests in mind' (Hagner 1995:555-556). The unusually high number of minor agreements between Matthew and Luke also causes confusion when the texts are compared. Most of the minor agreements can be attributed to the 'independent Matthean and Lukan redaction, although it is difficult to explain their great number' (Luz 1989:510). Klijn (1966:149-155) thinks that there were two different versions of the tradition about the rich young man, because Matthew differs so much from Mark and Luke.

The agreement in wording between Romans 13:9 and Matthew 19:18-19 does not help to determine the age and order of the respective Synoptic accounts of the rich young man. Romans 13:9 and Matthew 19:18-19 repeat a saying of Jesus. The Pauline parallel does not provide information on the narrative framework in which the saying of Jesus was delivered. The Pauline parallel cannot be used to argue for higher age of the Matthean account as a whole. Yet, because of the agreements between Matthew 19:18-19 and the older Romans 13:9, Matthew would have used a second source apart from Mark when writing down his account of the rich young man. Matthew follows Mark in the order of the Decalogue commandments, but Mark does not provide a template for Matthew's combination of the command to love the neighbour with a selection of Decalogue commandments.

The often encountered objections against assuming a relationship between the Pauline and Synoptic versions of 
the command to love the neighbour only apply when Romans 13:9 and Galatians 5:14 are compared with the great commandment. When comparing Romans 13:9 with Matthew 19:18-19, it is notable that the commandment to love God is found in neither of the texts. The observation that Paul never cites the great commandment does not disprove a connection between Romans 13:9 and Matthew 19:18-19. It also cannot be argued that Paul is contradicting a saying of Jesus because he omits the command to love God. That the single command to love the neighbour is found in these verses only is precisely what makes the proximity of these verses to each other so unmistakably clear. Combined with Paul's and Matthew's unique use of the command to love the neighbour together with a selection of Decalogue commandments, Romans 13:9 and Matthew 19:18-19 should be added as another parallel between the sayings of Jesus in the Pauline letters and the Synoptic Gospels.

\section{Acknowledgements Competing interests}

The authors declare that they have no financial or personal relationships which may have inappropriately influenced them in writing this article.

\section{Authors' contributions}

G.J.S. is the supervisor of H.A.H.'s PhD thesis called 'Paul's use of the Synoptic Jesus tradition'.

\section{References}

Allison, D.C., 1982, 'The Pauline epistles and the synoptic gospels: The pattern of the parallels', New Testament Studies 28, 1-32. http://dx.doi.org/10.1017/S0028688 parallels', New
500007232

Berger, K., 1972, Die Gesetzesauslegung Jesu. Ihr historischer Hintergrund im Judentum und im Alten Testament. Teil I: Markus und Parallelen, WMANT 40, Neukirchener Verlag, Neukirchen-Vluyn.
Dunn, J.D.G., 1993, The epistle to the Galatians, BNTC, Hendrickson Publishers, Peabody, MA.

France, R.T., 2007, The gospel of Matthew, NICNT 1, Eerdmans Publishing Company, Grand Rapids, MI.

Furnish, V.P., 1973, The love command in the New Testament, SCM Press, London.

Furnish, V.P., 1993, Jesus according to Paul, Cambridge University Press, Cambridge.

Haacker, K., 2006, Der Brief des Paulus an die Römer, ThHKNT 6, 3rd edn., Evangelische Verlagsanstalt, Leipzig.

Hagner, D.A., 1995, Matthew 14-28, Word Biblical commentary 33b, Word Books Publisher, Dallas, TX.

Johnson, L.K., 2005, The writings of the New Testament. An interpretation, 3rd rev. edn., SCM Press, London.

Kim, S., 2002, Paul and the new perspective. Second thoughts on the origin of Paul's gospel, Eerdmans Publishing Company, Grand Rapids, MI.

Klijn, A.F.J., 1966, 'The question of the rich young man in a Jewish-Christian Gospel', Novum Testamentum 8, 149-155. http://dx.doi.org/10.1163/156853666X00112

Lohse, E., 2003, Der Brief an die Römer, KEK 4, Vandenhoek \& Ruprecht, Göttingen.

Luz, U., 1989, Matthew 8-20, Hermeneia, Fortress Press, Minneapolis, MN.

Neirynck, F., 1986, 'Paul and the sayings of Jesus', Bibliotheca Ephemeridum Theologicarum Lovaniensiom 73, 265-321.

Schmid, U., 2013, 'Old Testament and New Testament versions of the mosaic law: The intersection of oral and written tradition', in M.K. Peters (ed.), XIV Congress of the International Organization for Septuagint and Cognate Studies Helsinki 2010 pp. 587-604, Society of Biblical Literature, Atlanta.

Schnelle, U. (ed.), 2009, Neuer Wettstein. Texte zum Neuen Testament aus Griechentum und Hellenismus, Bd. I/1.1, Texte Markusevangelium, Walter de Gruyter, Berlin.

Schnelle, U., 2014, Paulus. Leben und Denken, 2nd edn., Walter de Gruyter, Berlin.

Steyn, G.J., 1996, 'Pretexts of the second table of the Decalogue and early Christian intertexts', Neotestamentica 30(2), 451-464.

Steyn, G.J., 2013, 'A comparison of the Septuagint textual form in the Torah quotations common to Philo of Alexandria and the Gospels of Mark and Matthew', in M.K.
Peters (ed.), XIV Congress of the International Organization for Septuagint and Peters (ed.), XIV Congress of the International Organization for Septuagint and
Cognate Studies Helsinki 2010, pp. 605-624, Society of Biblical Literature, Atlanta.

Strack, H. \& Billerbeck, P., 1979, Kommentar zum neuen Testament. Die Briefe des Neuen Testaments und die Offenbarung des Johannes III, 7th edn., C. H. Beck, München.

Walter, N., 1985, 'Paulus und die urchristliche Jesustradition', New Testament Studies 31, 498-522. http://dx.doi.org/10.1017/S0028688500012054

Wiefel, W., 1998, Das Evangelium nach Matthäus, ThHKNT 1, Evangelische Verlagsanstalt, Leipzig.

Wilckens, U., 2010, Der Brief an die Römer, EKK Studienausgabe, Neukirchener Verlag, Neukirchen-Vluyn \& Patmos Verlag, Mannheim.

Wilson, S.G., 1984, 'From Jesus to Paul: The contours and consequences of a debate', in P. Richardson \& J.C. Hurd (eds.), From Jesus to Paul. Studies in honour of Francis Wright Beare, pp. 1-21, Wilfrid Laurier University Press, Waterloo.

Wischmeyer, O., 1986 'Das Gebot der Nächstenliebe bei Paulus. Eine traditionsgeschichtliche Untersuchung', Biblische Zeitschrift 30, 161-187. 